Austrian Academy of Sciences \& Alpen-Adria-University Klagenfurt, Vienna, Austria

\title{
The German News Coverage of Poland during the Polish EU Presidency Term in 2011
}

\section{Introduction}

Des the EU presidency offer the potential for the country holding this position to change its image among the other member states of the European Union? Does the 6-month period of the presidency draw more attention to the country holding the position, not only because it will be a host of a number of EU events and meetings, but also because it is the actor in charge to define the directions of the EU policy for the given period? And beyond this political dimension, what are the other dimensions in which the respective country is being observed throughout its presidency, and does the overall frame of perception change during the term of office? Against the backdrop of those guiding research questions of this the special issue of the Central European Political Studies, the German news coverage on Poland was identified and analyzed during the Polish EU Presidency term in 2011. The results of this content analysis are subsequently briefly discussed and elaborated against the country-specific cultural and contextual setting of this news coverage.

\section{The German Media Sample}

For the German country case, we analyzed the German news coverage for the time frame between June 15, 2011, and January 15, 2012, focusing however on the core periods [1] 15 June - 31 July 2011, [2] 01 September - 15 October 2011, and [3] 01 December 2011 - 15 January 2012. The sample included two daily quality newspapers (Frankfurter Allgemeine Zeitung FAZ, Süddeutsche Zeitung SZ) and one daily tabloid newspaper $(B i l d)$. All three newspapers are nationally available and have the largest distribution rates in Gera (Hans-Bredow-Institut für Medienforschung, 
2009; World Editors Forum/World Association of Newspapers, 2009). In addition to that, the leading weekly news magazine (Der Spiegel) was analyzed. All articles were searched ${ }^{1}$ and acquired from online databases and were saved as digital files (PDF format). For acquiring the articles, we used the digital archives of the $F A Z$ and $S Z$, the general digital archive wiso Presse for Der Spiegel (accessible via the Austrian National Library), the Mikrofilmarchiv in Dortmund and for the tabloid Bild.

For each newspaper/weekly magazine and analyzed publication day, the whole newspaper edition was searched and all journalistic materials (e.g., news items comments, reports, editorials) were included. Sunday editions were only included for the FAZ, but not for the Bild (Bild am Sonntag), since this format does not follow the regular format of the daily edition throughout the week. We did not include "local" news articles in the sample, if those sections vary between the local editions of newspapers. This also applies to "sport" articles only found for regional editions of the newspapers. Last but not least, we did not include sports news items that simply consisted of results tables; if sports results were presented, the text had to include at least one additional full sentence.

We carried out a pre-test analysis for 120 articles, being coded by three coders, for a general test of the correct use and understanding of the codebook. Subsequently we did an intercoder reliability test. ${ }^{2}$ The intercoder reliability test was again carried out after the analysis was completed. ${ }^{3}$ In the following, for the general description only the total numbers are presented, i.e. for each analytical variable the total numbers including all analyzed print media are presented. Furthermore, all calculations and numbers presented in this paper are in percentages (shares of the total German sample that was analyzed). This form of presentation allows for better comparing of the results and their relevancies with the other country samples in this special issue of the Central European Political Studies.

1 To identify relevant articles and based on the project instructions, we used the search keywords "Polen", "Polens", "Pole", "Polin", "Polinnen", "polnisch", "polnische", "polnischer", "polnisches", "polnischem", and "polnischen".

2 Using the Holsti's coefficient of reliability (calculated with PRAM); coefficients for the coded variables ranked between .856 and .751 , with the exception of XII.Topic 1-3 where the coefficient was below 0.4 for all three variables.

3 Using the Holsti's coefficient of reliability (calculated with PRAM); coefficients for the coded variables ranked between .846 and .732 , again with the exception of XII.Topic 1-3 where the coefficient was below 0.4 for all three variables. Thus we excluded these variables from a comparative analysis. 


\section{The German News Coverage of Poland during the Polish EU Presidency Term in 2011}

\section{The Overall Publication Output}

Altogether, we identified 1.353 news items (i.e. newspaper articles) in the analyzed German print media for the focused on time frame. As Table 1 outlines, we identified most articles in the German quality daily newspaper $F A Z$, followed by the second quality daily newspaper $S Z$. Compared to that, the daily tabloid Bild, provided the least amount of articles referring to Poland. In the weekly newsmagazine Der Spiegel altogether 55 articles were identified that included references to Poland. References to the EU Presidency were only identified in 74 of those articles relating to Poland. That only adds up to 5.5 percent of the overall sample, and those articles were almost solely found in the two quality dailies, while in Bild and in Der Spiegel the EU presidency topic was almost completely absent from the news coverage on Poland over the analyzed timeframe.

Table 1

German Data Sample

\begin{tabular}{||l|c|c||}
\hline \multicolumn{1}{|c|}{ German print media } & $\begin{array}{c}\text { Number } \\
\text { of articles }\end{array}$ & Percentages $^{\mathbf{4}}$ \\
\hline Süddeutsche Zeitung (daily quality newspaper) & $467\left(25^{*}\right)$ & $34.5(1.8)$ \\
\hline Frankfurter Allgemeine Zeitung (daily quality newspaper) & $676(47)$ & $50.0(3.5)$ \\
\hline Bild (daily tabloid newspaper) & $155(1)$ & $11.5(0.1)$ \\
\hline Der Spiegel (weekly newsmagazine) & $55(1)$ & $4.1(0.1)$ \\
\hline Total sample size & $\mathbf{1 . 3 5 3 ( 7 4 )}$ & $\mathbf{1 0 0 . 0 ( 5 . 5 )}$ \\
\hline
\end{tabular}

* Articles with References to Poland AND EU Presidency.

Distinguishing the pre-, during-, and post-presidency time periods, Table 2 shows that while the news coverage on Poland in general increased slightly during and after the country's presidency term, the news coverage on the EU Presidency in that context did not increase with the start of the Polish term on July 1, 2011. Rather the opposite effect can be observed: Whereas in the pre-presidency period approximately 6.7 percent of the

4 Percentages refer to the share of the overall sample. 
overall number of articles with Polish reference in the analyzed German media related to the EU Presidency, during the Polish presidency term, the share of those articles dropped to 5.5 percent during the term and further decreased to 4.1 percent after the end of the term.

The same observation was made for the average news coverage per publication day distinguished according to the three time periods: When we define the arithmetic mean for the number of identified articles before, during and after the presidency term, we see that the news attention for Poland in general increases slightly during the presidency term: Before the term, an average of nine articles per publication day included references to Poland; during the term the average increased to ten articles, and after the presidency term ended the number decreased again to eight articles per publication day. Thus an increase in news coverage and thus media attention paid towards Poland in general due to the Polish presidency term can be observed in the German media. The same was observed for articles that also relate to the EU presidency in some way: Before and during the Polish EU Presidency term, the average news coverage here was 0.6 articles per publication day; after the end of the Polish term this average dropped to only 0.3 percent.

Table 2

Do the Articles Relate to the EU Presidency?

\begin{tabular}{||l|c|c|}
\hline \hline & $\begin{array}{c}\text { Reference to } \\
\text { EU presidency }\end{array}$ & $\begin{array}{c}\text { No reference to } \\
\text { EU presidency }\end{array}$ \\
\hline Pre-presidency & $6.7^{*}$ & 93.3 \\
\hline During presidency & 5.5 & 94.5 \\
\hline Post-presidency & 4.1 & 95.9 \\
\hline \% of total sample & $\mathbf{5 . 5}$ & $\mathbf{9 4 . 5}$ \\
\hline
\end{tabular}

* In \% of All Articles Identified Per Time Period.

Thus overall, the news attention towards Poland has not significantly increased with the country's takeover of the EU Presidency. Also, the results already indicate that the German news perspective may not be centrally shaped by this role; over 90 percent of articles do not relate to it when taking Poland into view. This observation will be analyzed in more detail at a later point when the thematic areas of the news coverage are discussed.

However, another observation we made throughout the analysis was that in some articles in the German sample, the connection between Po- 
land and the country being the current holder of the EU Presidency is not explicitly mentioned. Instead, this connection could only be derived from the context or topic of the article, for instance, when a meeting of EU officials took place in Poland due to the fact that Poland was holding the presidency at the time. In other cases, one newspaper would explicitly relate Poland to the presidency in such a context, while another only reports on the meeting without giving this information.

News Trends throughout the Polish EU Presidency Term

When we look at the trend of the overall news coverage in the analyzed German sample throughout the total timeframe of the analysis (in absolute numbers of articles, for all analyzed media together), we see that the news coverage has not been balanced and consistent. Instead, we identified fluctuations and high peaks of news coverage (i.e. days/weeks that showed an increased number of articles relating to Poland, or to Poland as well as the EU Presidency).

Regarding the general news coverage on Poland, altogether we identified nine high peaks in the German news media sample (Table 3). The news coverage on Poland increases before and in the first days of the start of Polish EU Presidency (Peak 1 and 2), but more significant peaks were identified in the middle of the presidency term (Peak 5 and 7). This supports the observation outlined before already, namely that the presidency term did not have the most significant impact on the general level of attention paid to Poland. When looking at the topics actually focused on in the articles of those peak times, this observation is confirmed, showing that the increased attention is not mainly based on the impact of the presidency term.

Table 3

Trigger Events and Topics during Publication Peaks

\begin{tabular}{|c|c|c|}
\hline Peak 1 & 20-22 Jun & $\begin{array}{l}\text { - international and EU politics (NATO mission to Syria; German visit to } \\
\text { Poland; EU accession of Croatia) } \\
\text { - social study on prejudices in CEE countries (German Friedrich Ebert Fo- } \\
\text { undation) } \\
\text { - plane crash in Russia (comparison with airplane crash in } 2010 \text { when the } \\
\text { Polish President and other government officials died) } \\
\text { - sport news (diverse competitions with Polish participation or hosted by } \\
\text { Poland; EURO2012 Qualifications) }\end{array}$ \\
\hline
\end{tabular}




\begin{tabular}{|c|c|c|}
\hline Peak 2 & 01-02 Jul & $\begin{array}{l}\text { - EU politics (Polish EU Presidency term, EU budget, EU politics in general) } \\
\text { - economy news (German companies etc. and their international relations; } \\
\text { European energy politics) }\end{array}$ \\
\hline Peak 3 & $25 \mathrm{Jul}$ & $\begin{array}{l}\text { - EU politics (Schengen negotiations and Danish border issues; Euro crisis) } \\
\text { - economy news (Euro crisis) } \\
\text { - sport news (boxing match between German and Polish boxer) }\end{array}$ \\
\hline Peak 4 & $30 \mathrm{Jul}$ & $\begin{array}{l}\text { - EU politics (Schengen regulations; agriculture agreements) } \\
\text { - internal politics (release of final report on plane crash in } 2010 \text { when the } \\
\text { Polish President and other government officials died) } \\
\text { - sport news (Qualifications for Football World Cup in Brazil 2014) }\end{array}$ \\
\hline Peak 5 & 05-12 Sep & $\begin{array}{l}\text { - EU politics (meeting of EU foreign ministers in Sopot, PL) } \\
\text { - economy news (financial markets in CEE) } \\
\left.\text { - cultural news (history - German-Polish relations, NS era, } 2{ }^{\text {nd }} \mathrm{WW}\right) \\
\text { - sport news (EURO2012 Qualifications; diverse other competitions) }\end{array}$ \\
\hline Peak 6 & 19 Sep & $\begin{array}{l}\text { - EU politics/economy news (meeting of EU financial ministers in Breslau } \\
\text { and Wroclaw, financial crisis, energy resources) } \\
\text { - cultural news (visit of the Pope in Germany, Catholics in Poland and Ger- } \\
\text { many) }\end{array}$ \\
\hline Peak 7 & 08-14 Oct & $\begin{array}{l}\text { - internal politics (Polish parliamentary elections, } 09 \text { Oct) } \\
\text { - economy news (Polish economic/financial situation; financial situation } \\
\text { in EU countries; German companies etc. in CEE countries) } \\
\text { - cultural news (Reviews with Polish references/Polish artists, e.g. } 2^{\text {nd }} \\
\text { WW/Nazi era) } \\
\text { - } \text { sport news (EURO2012 Qualifications; diverse competitions) }\end{array}$ \\
\hline Peak 8 & $03 \mathrm{Dec}$ & $\begin{array}{l}\text { - EU politics (meeting of EU leaders and financial ministers in Brussels; } \\
\text { negotiations of EU treaty; Euro crisis) } \\
\text { - economy news (financial situation in CEE, Poland; Euro crisis) } \\
\text { - } \text { sport news (EURO2012, Handball CL) }\end{array}$ \\
\hline Peak 9 & 08 Dec & $\begin{array}{l}- \text { EU politics (Euro crisis, EU summit in Brussels) } \\
\text { - economy news (Polish economy/growth rates; credit rating of EU coun- } \\
\text { tries) } \\
\text { - crime news (arrest of criminal fraud gang - Polish connection) } \\
\text { - sport news (EURO2012, European Basketball) }\end{array}$ \\
\hline
\end{tabular}

With regard to articles in the German sample that also included references to the EU Presidency, only two high peaks can be identified, the first peak being between June 30 and July 2, 2011 - i.e. at the official start of the Polish EU Presidency term, with articles mainly focusing on that specific topic (2 others focus on the Greece financial crisis and the EU bailout plans) - and the second peak between September 14-17, 2011. Here, only one article specifically focused on the Polish presidency performance, while the increased news coverage was instead triggered by the meeting of the EU financial ministers in Breslau. The key topic in this context was the solving of the Euro crisis. In the context of those articles, Poland received 
only a minor focus, and was mainly mentioned as host of the meeting or as being the current holder of the presidency. At the same time, during the Polish presidency term there are also longer phases (e.g., in December) with no news cover on Poland in the context of the EU Presidency.

\section{Placement and Layout of the News Items}

Altogether, the majority of articles we identified that included references to Poland are placed within the newspaper/newsmagazine edition (Table 4). Only 3.6 percent of the articles were either placed on the front page ( 2.8 percent) or on the front paged with continuation in the newspaper $(0.8$ percent $)$. When we only look at the articles including references to the EU Presidency, overall the large majority of those articles (5.0 percent) were found within the newspaper edition, too, while only 0.4 percent of them were placed either on the front page ( 0.2 percent) or on the front page with continuation in the newspaper ( 0.2 percent). Thus, we can say that regarding the visibility of the EU presidency, the topic did not receive a prominent position in the analyzed German print media sample.

Table 4

Placement of Articles Relating to Poland

\begin{tabular}{||l|c|c|c|}
\hline \multicolumn{1}{|c|}{ Placed o } & front page & $\begin{array}{c}\text { front page } \\
\text { and continued }\end{array}$ & other page \\
\hline Pre-presidency & $2.0^{*}$ & 1.3 & 96.7 \\
\hline During presidency & 3.2 & 0.8 & 95.9 \\
\hline Post-presidency & - & - & 100.0 \\
\hline \% of total sample & $\mathbf{2 . 8}$ & $\mathbf{0 . 8}$ & $\mathbf{9 6 . 4}$ \\
\hline
\end{tabular}

* In \% of All Articles Identified Per Time Period.

Overall, we see that the number of front page articles is at its highest rate during the Polish EU Presidency term, whereas after the end of the term, Poland disappears completely from the front pages of the analyzed German print media. References to the EU presidency on the front page are most frequently found before ( 0.7 percent front page and continued) and during the presidency term ( 0.3 percent front page; 0.2 percent front page and continued). Nevertheless, as is the case with the overall sample of articles relating to Poland, the majority of articles were placed within 
the newspaper edition throughout the time frame of the analysis (6.0/5.0/4.1 percent before during and after the presidency). Thus, even though the number of front page articles increases, one has to be careful with drawing the conclusion here that Poland altogether moved more to the center of the German news agenda.

Genres: The majority of articles with references to Poland are simple news articles, followed by more complex news reportages (Table 5). For articles with both references to Poland and to the EU Presidency, two other significant categories are columns and commentaries (each 0.4 percent), which indicates that articles reporting on EU Presidency-related topics may be more opinion-oriented and evaluative.

Table 5

Genre of Articles Relating to Poland

\begin{tabular}{||l|c|c|c|c|c|c|c|c||}
\hline \multicolumn{1}{|c|}{ Genres } & News & $\begin{array}{c}\text { Repor- } \\
\text { tage }\end{array}$ & $\begin{array}{c}\text { Edit } \\
\text { orial }\end{array}$ & Column & $\begin{array}{c}\text { Com- } \\
\text { mentary }\end{array}$ & $\begin{array}{c}\text { Guest } \\
\text { contri- } \\
\text { bution }\end{array}$ & $\begin{array}{c}\text { Inter- } \\
\text { view }\end{array}$ & $\begin{array}{c}\text { Letter to } \\
\text { editor }\end{array}$ \\
\hline $\begin{array}{l}\text { Pre- } \\
\text { presidency }\end{array}$ & $40.0^{*}$ & 30.7 & 1.3 & 2.7 & 1.3 & 2.0 & 3.3 & 4.0 \\
\hline $\begin{array}{l}\text { During } \\
\text { presidency }\end{array}$ & 40.7 & 31.9 & 0.7 & 5.7 & 1.9 & 1.9 & 1.7 & 2.2 \\
\hline $\begin{array}{l}\text { Post- } \\
\text { presidency }\end{array}$ & 41.5 & 30.1 & - & 4.9 & - & 0.8 & 4.9 & 0.8 \\
\hline $\begin{array}{l}\text { \%o of total } \\
\text { sample }\end{array}$ & $\mathbf{4 0 . 7}$ & $\mathbf{3 1 . 6}$ & $\mathbf{0 . 7}$ & $\mathbf{5 . 3}$ & $\mathbf{1 . 7}$ & $\mathbf{1 . 8}$ & $\mathbf{2 . 1}$ & $\mathbf{2 . 3}$ \\
\hline
\end{tabular}

* In \% of All Articles Identified Per Time Period.

The number of simple news articles increases throughout the time frame of the analysis for articles including references to Poland. The number of more complex reportages is highest during the Polish presidency term, as is the number of columns. When only looking at articles with EU presidency references, the number of simple news articles is highest before (3.3 percent) and during ( 3.2 percent) the presidency term, while no news items have been found after the term ended. Instead we identified a steady and significant increase in more complex reportages $(0.7 / 1.2 / 3.3$ percent before/during/after presidency), while opinion-related genres such as editorials, columns, commentaries or interviews are most frequent before the start of the Polish presidency term. This indicates that a deeper reflection on the Polish presidency performance is predominantly given 
before the term started, mainly by focusing on expectations that are addressed towards Poland in that context. ${ }^{5}$

Altogether, for the German sample we can summarize that the news coverage throughout the presidency term does become slightly more complex (e.g., indicated by news reportages) but decreases in variety and evaluation (e.g., indicated by opinion-related formats such as columns, or commentaries). However, as we will see with regard to the topics focused on, this increase in complexity of the news coverage does not necessarily happen in the area of EU-politics-related news, but is rather caused by other factors. As concerns the EU presidency topic, we find rather a decrease in complexity of the news coverage throughout the term.

Table 6 summarizes the use of visual elements in the German news coverage on Poland. Overall 45.9 percent of the articles include no visual images. However, we also find a larger number of articles that include one or several pictures, while other forms of visual images or a combination of more than one form are only minor relevant in the German sample. Thus, altogether about half of the identified articles with references to Poland are enhanced in their level of visibility for the reader by a visual element.

Visual Images in Articles Relating to Poland

Table 6

\begin{tabular}{||l|c|c|c|c|c|c||}
\hline \multicolumn{1}{|c|}{ Used images } & Picture(s) & Map(s) & $\begin{array}{c}\text { Car- } \\
\text { toon(s) }\end{array}$ & Table(s) & $\begin{array}{c}\text { A few } \\
\text { types }\end{array}$ & $\begin{array}{c}\text { No visual } \\
\text { elements }\end{array}$ \\
\hline Pre-presidency & $46.7 *$ & 0.7 & 0.7 & 3.3 & 4.0 & 44.7 \\
\hline During presidency & 45.9 & 0.6 & 1.0 & 3.0 & 2.6 & 46.9 \\
\hline Post-presidency & 48.8 & 2.4 & 0.8 & 2.4 & 6.5 & 39.0 \\
\hline \% of total sample & $\mathbf{4 6 . 3}$ & $\mathbf{0 . 8}$ & $\mathbf{1 . 0}$ & $\mathbf{3 . 0}$ & $\mathbf{3 . 1}$ & $\mathbf{4 5 . 9}$ \\
\hline
\end{tabular}

* In \% of All Articles Identified Per Time Period.

The use of pictures is high during the whole timeframe of the analysis; the same can be observed for the ranking of only EU Presidency-related articles (1.3/1.9/1.6 percent before/during/after the presidency term). On a minor level, also tables were used before the presidency term, while after the presidency term we find an increase in articles that included a combi-

5 We also found a share of 13.7 percent of articles coded as 'other', which includes formats such as book, film or art reviews, event notes for exhibitions etc., portraits, or word definitions. 
nation of different visual elements (mostly a combination of pictures and tables or maps). In a reverse trend, articles with no visual elements first increased during the presidency and dropped significantly after the term. When only looking at EU presidency-related articles, pictures were mostly used during the Polish presidency term (1.9 percent) while articles after the end of the term included more combinations of visual elements (0.8 percent).

On average, only every third to fourth article using visual elements also includes references to Poland in the same. The significance strongly depends on the visual element used: In pictures, references to Poland are fewest, and they decrease steadily throughout the timeframe of the analysis. In contrast to that, we find references to Poland in every used map before the presidency term and every second during the term. For tables, numbers are lower, but still more than half of them include a reference to Poland in the pre-presidency time period. As for articles that combine different forms of visual images, the references to Poland increase especially after the end of the presidency term. Those numbers stem from the fact that many of those maps or tables compare data or overviews of different European country (e.g., relating to economy or sport news). Being an EU country, Poland is often simply listed in those contexts, without actually being the central focus of the article, as well.

In articles also relating to the EU Presidency, the number of articles using pictures that also referred to Poland is significantly higher than the average number for all articles of the German sample: Before the Polish presidency term, in 50.0 percent of those articles also the used picture(s) refer to Poland; during the term, 40.0 percent of the pictures do. After the presidency term, every third articles referring to the presidency includes a combination of different types of visual images.

\section{Sources Given in the News Coverage}

When we look at the sources being provided in the news coverage on Poland, we first of all distinguished between sources provided in news material and sources of opinion material. 79.3 percent of the identified articles with references to Poland are news items, 20.7 percent opinion items (Table 7). For articles also relating to the EU Presidency, the share is slightly different; here on average more news items (85.1 percent) and less opinion items (14.9 percent) were found, indicating again that with regard 
to the EU presidency topic less evaluating content was published in the German sample than on average when Poland was also taken into view.

Table 7

Share of News and Opinion Material for Articles Relating to Poland and Poland and EU Presidency

\begin{tabular}{||l|l|l||}
\hline & \multicolumn{1}{|c|}{ News items } & \multicolumn{1}{c|}{ Opinion items } \\
\hline Share in the total sample & $79.3 \%(1.073$ articles $)$ & $20.7 \%(280$ articles $)$ \\
\hline $\begin{array}{l}\text { Share in sample with references to EU presi- } \\
\text { dency }\end{array}$ & $85.1 \%(63$ articles $)$ & $14.9 \%(11$ articles $)$ \\
\hline
\end{tabular}

Table 8 summarizes the sources of information provided in the news material relating to Poland. ${ }^{6}$ Surprisingly, compared to other country samples, only 10.7 percent of the analyzed German news articles do not provide any news sources. 12.5 percent of articles name national news agencies as their source of information (predominantly $D P A^{7}$ ). The majority of articles list author names as the main source of the respective news item, which is summarized in the category "other sources". When only looking at the ranking for articles relating to the EU Presidency, again most of the articles provide "other sources" (i.e. authors) as the source of information (4.8 percent). 0.2 percent give no sources, while respectively 0.4 percent of the articles are based on information retrieved from national news agencies (mainly DPA) or foreign/international news agencies (e.g., AFP, ${ }^{8}$ Reuters).

Table 8

Sources in News Material Relating to Poland

\begin{tabular}{||l|c||}
\hline \multicolumn{1}{|c|}{ Source of news material } & In \% of all news material \\
\hline \multicolumn{1}{|c|}{1} & 2 \\
\hline National news agency & 12.5 \\
\hline Foreign international news agency & 1.3 \\
\hline Other national media & 0.3 \\
\hline
\end{tabular}

${ }^{6}$ The variables analyzed in this section are only illustrated for the overall timeframe of the analysis, arguing that if newspapers have a specific habit of dealing with the revealing of their news sources, this should be a permanent procedure that is not affected by the content of the news coverage.

\footnotetext{
${ }^{7}$ Deutsche Presseagentur.

8 Agence France-Presse.
} 


\begin{tabular}{||l|c||}
\hline \multicolumn{1}{|c|}{1} & 2 \\
\hline Other foreign media & 1.9 \\
\hline Others (authors etc.) & 72.2 \\
\hline National and foreign media organizations & 0.1 \\
\hline Any news agency and any media organization & 1.0 \\
\hline None & 10.7 \\
\hline
\end{tabular}

Finally, Table 9 lists what kind of author is given as the source for the news items. Here we see that the vast majority of authors are staff members of the respective newspaper or news magazine. The only other form found in the German sample is guest authors. When only looking at the authors given in the EU Presidency-related articles, authors are solely staff members of the respective newspaper.

Table 9

Share of Author Types in News Material Relating to Poland

\begin{tabular}{||l|c|}
\hline \multicolumn{1}{|c|}{ Author types in news material } & $\begin{array}{c}\text { Share of all articles giving } \\
\text { authors as sources (in \%) }\end{array}$ \\
\hline Staff member of news organization & 99.4 \\
\hline Other (e.g. guest author) & 0.6 \\
\hline
\end{tabular}

Table 10 distinguishes the kind of authors of opinion items in the respective newspapers articles. Altogether, the author sources in opinion material are rather varied, even though the majority was written by journalists. The category "citizen" mainly refers to opinion pieces contributed by readers in form of "letters to the editor".

Author Sources in Opinion Material Relating to Poland

\begin{tabular}{||l|c|}
\hline $\begin{array}{c}\text { Author types in opinion } \\
\text { material }\end{array}$ & $\begin{array}{c}\text { In \% of all opinion } \\
\text { material }\end{array}$ \\
\hline Editorial staff & 1.1 \\
\hline Journalist & 76.1 \\
\hline National politician & 1.8 \\
\hline Foreign politician & 0.7 \\
\hline National expert & 5.7 \\
\hline Foreign expert & 1.8 \\
\hline Citizen & 9.6 \\
\hline Other & 3.2 \\
\hline
\end{tabular}


We also find a number of pieces being written by national experts, even though this category may be due to a large number of articles being identified in the sports section. Only 1.1 percent of contributions are editorial texts. It should be pointed out, however, that compared to the news items in none of the opinion items a source is missing. When looking only at those opinion items that are also EU Presidency-related, we find less variety in the author sources: The decisive majority of those opinion items are written by journalists ( 3.2 percent); the rest equally gives either foreign politicians or citizens as the author source ( 0.4 percent each).

\section{Thematic Areas of the News Coverage on Poland}

As pointed out earlier, only a small number of articles that were identified to focus on or refer to Poland also address the aspect of the EU Presidency. This already indicates that other thematic areas shape the news coverage in the context of which Poland comes into view. Table 11 illustrates that a broad variety of thematic areas is covered in German print media when Poland is mentioned or focused on. Most frequently addressed is the area "sport", followed by "culture", "international politics", and "economy".

Table 11

Thematic Areas in Articles Relating to Poland

\begin{tabular}{||l|c|c|c|c||}
\hline $\begin{array}{c}\text { Dominant topics of the } \\
\text { news articles }\end{array}$ & Pre-presidency & $\begin{array}{c}\text { During } \\
\text { presidency }\end{array}$ & $\begin{array}{c}\text { Post-presiden- } \\
\text { cy }\end{array}$ & $\begin{array}{c}\text { \% of total } \\
\text { sample }\end{array}$ \\
\hline Internal politics & $8.7^{*}$ & 8.2 & 6.5 & $\mathbf{8 . 1}$ \\
\hline International politics & 18.7 & 14.5 & 8.1 & $\mathbf{1 4 . 4}$ \\
\hline Economy & 9.3 & 14.6 & 12.2 & $\mathbf{1 3 . 8}$ \\
\hline Military and defense & 2.0 & 0.9 & - & $\mathbf{1 . 0}$ \\
\hline Justice and crime & 4.7 & 3.8 & 1.6 & $\mathbf{3 . 7}$ \\
\hline Culture & 22.7 & 18.2 & 22.0 & $\mathbf{1 9 . 1}$ \\
\hline Social relations & 3.3 & 4.9 & 5.7 & $\mathbf{4 . 8}$ \\
\hline Science and technology & 1.3 & 1.8 & 3.3 & $\mathbf{1 . 8}$ \\
\hline Environment & 0.7 & 0.8 & 1.6 & $\mathbf{0 . 9}$ \\
\hline Sport & 22.0 & 27.1 & 32.5 & $\mathbf{2 7 . 1}$ \\
\hline Human interest & 4.0 & 3.9 & 4.1 & $\mathbf{3 . 9}$ \\
\hline Accidents and disasters & 2.7 & 0.5 & 0.8 & $\mathbf{0 . 7}$ \\
\hline Other & - & 0.6 & 1.6 & $\mathbf{0 . 7}$ \\
\hline \hline
\end{tabular}

* In \% of All Articles Identified Per Time Period. 
In the area "sport", articles mainly focus on specific teams, coaches or athletes, player transfers, sport results, or international championships, and here in particular the EURO2012 qualification matches. In the area of "culture", Poland is mainly addressed in the context of articles that report on art or artists (in of from Poland, or with references to Poland), or that give reviews of books, music, or performance. A second topic is history, and here specifically the Second World War, in the context of which Poland is taken into view either as a place where the war took place, via contemporary witnesses of that time that were involved in the war or were victims of the same, or via specific topics or events that took place during the Nazi era or war time. A third topic is media productions with content about Poland. In the area of "international politics", Poland is mainly referred to in the context of articles on EU relations. Other subtopics are international tensions and agreements, or foreign visits of individual politicians (in or from Poland). In the area of "economy", a number of articles focus on the global economic crisis and its impact on the economic situation in the EU region or in specific EU countries, as well as on (Euro) currency-related topics. Minor subtopics are the state of economy and the job market in the countries of the Eurozone.

When looking only at those articles that also relate to the EU Presidency, we see that - not surprisingly - the central thematic area focused on is "international politics" (4.4 percent). Nevertheless, besides the fact that the EU Presidency is itself a topic placed in the dimension of international (EU) politics, it is also referred to in the context of areas such as "internal politics" (0.4 percent), "environment" (0.2 percent), "economy", “culture", or "science and technology" (each 0.1 percent).

However, the political dimension (internal and international politics) is not the central dimension of the news coverage during the Polish presidency term, but is actually constantly declining throughout the overall timeframe of our analysis, while, for instance, articles in the area of "economy" are increasing in frequency during the presidency term. Cultural topics drop in frequency during the presidency term, whereas the area of "sport" increases significantly during the presidency term and reaches its high peak in the two weeks after the presidency term. Here, clearly the news coverage centering on the upcoming EURO2012 has already an effect on the overall news coverage in relation to Poland (during the time frame of the analysis several qualification matches took place). Finally, in the timeframe during the presidency term (and only then), one event that caused a higher number of articles with references to Poland in the area of internal politics is the Polish elections that took place in October 2011. 
In articles also relating to the EU Presidency, the only relevant thematic area "international politics" decreases significantly throughout the timeframe of the analysis (6.0/4.4/2.4 percent before/during/after the presidency), while after the end of the Polish presidency term the areas "environment" and "science and technology" become significant $(0.8$ percent each). The central subtopic in the area of "international politics" is EU relations, while in the area of "environment" subjects are EU negotiations about the EU Emission Trading scheme and the Polish position on this topic, or a UN climate summit in Durban. However, no exact statement can be made for the general thematic embedding of the EU Presidency news coverage, since for the comparative analysis only those articles were included that also related to Poland.

Overall, Poland is in many cases only minor relevant in the respective articles, i.e. Poland does not have a central role in the respective article but is, for instance, only one of several countries referred to as a comparison when economic rankings of EU countries are reported on. Or actors in the articles are simply mentioned to have Polish ancestors or origin (e.g. in sport-, history- or art-related articles). Finally, in the context of sport articles, Poland is often simply mentioned as the place of a sport event.

\section{Domestication - Reference to Germany in the News Coverage on Poland}

Regarding possible domestic references to Germany in articles relating to Poland, either by mentioning or discussing German nationals in text or visual images, or by relating to an impact on Germany by whatever is reported on in the respective article, Table 12 lists the quantitative share of such domestic references.

Table 12

Domestic References to Austria

\begin{tabular}{||c|c|c|c|c|c|c||}
\hline $\begin{array}{c}\text { Domestic } \\
\text { references } \\
\text { to }\end{array}$ & $\begin{array}{c}\text { German } \\
\text { nationals }\end{array}$ & $\begin{array}{c}\text { The } \\
\text { impact } \\
\text { on } \\
\text { Germany }\end{array}$ & $\begin{array}{c}\text { German na- } \\
\text { tionals and } \\
\text { Germany } \\
\text { in visual } \\
\text { elements }\end{array}$ & $\begin{array}{c}\text { German } \\
\text { nationals } \\
\text { and } \\
\text { impact on } \\
\text { Germany }\end{array}$ & $\begin{array}{c}\text { German natio- } \\
\text { nals, impact on } \\
\text { Germany, and } \\
\text { Germany in } \\
\text { visual elements }\end{array}$ & $\begin{array}{c}\text { No } \\
\text { reference } \\
\text { to Germany }\end{array}$ \\
\hline 1 & 2 & 3 & 4 & 5 & 6 & 7 \\
\hline $\begin{array}{l}\text { Pre- } \\
\text { presidency }\end{array}$ & $44.0^{*}$ & - & 15.3 & 15.3 & 10.0 & 15.3 \\
\hline
\end{tabular}




\begin{tabular}{||l|c|c|c|c|c|c||}
\hline \multicolumn{1}{|c|}{1} & 2 & 3 & 4 & 5 & 6 & 7 \\
\hline $\begin{array}{l}\text { During } \\
\text { presidency }\end{array}$ & 42.3 & 0.1 & 13.5 & 12.7 & 11.2 & 20.2 \\
\hline $\begin{array}{l}\text { Post- } \\
\text { presidency }\end{array}$ & 39.8 & - & 18.7 & 10.6 & 12.2 & 18.7 \\
$\begin{array}{l}\text { \% of total } \\
\text { sample }\end{array}$ & $\mathbf{4 2 . 3}$ & $\mathbf{0 . 1}$ & $\mathbf{1 4 . 2}$ & $\mathbf{1 2 . 8}$ & $\mathbf{1 1 . 2}$ & $\mathbf{1 9 . 5}$ \\
\hline
\end{tabular}

* In \% of All Articles Identified Per Time Period.

Overall, one fifth of the articles do not include any references to Germany. If Germany is referred to, it is predominantly in form of references made towards German nationals. In some articles we find a combination of references to German nationals and to Germany in the visual elements used, followed by articles that include references to German nationals in combination with references to the impacts of a discussed issue on Germany. Finally, some refer to German nationals, the impact on Germany, and include references to Germany in their visual elements. Thus overall, the central level of domestication is the reference to Germany nationals. When only looking at articles that also relate to the EU Presidency, we see that a large number of those articles are indeed foreign news coverage (no reference to Germany, 2.0 percent). However, a larger share of articles includes references to German nationals ( 2.3 percent), followed by articles including references to German nationals and the impact of the respective an issue on Germany ( 0.7 percent). Thus, a significant number of the German articles do not have a solely foreign focus when taking Poland into view. Also, Poland is in many cases not a central but only a side-focus of the respective news coverage. A number of articles actually focus on German (not only in the context of internal politics, but also with regard to economic issues, and first and foremost in the context of sport topics).

The share of domestic references to German nationals decreases slightly throughout the timeframe of the analysis, as does the share of articles that refer both to nationals and to the impact of the respective issue on Germany as a country. The number of articles with no domestication (i.e., solely foreign news coverage) is highest during the presidency term. This indicates an overall shift of attention away from German topics towards a more outward focus on foreign issues (and Polish ones in particular). A the same time, a declining focus on Germany in the context of the identified articles does not necessarily mean a stronger turn towards Poland and 
thus an increasing focus on Poland due to the EU Presidency. Rather, we could argue that articles on Poland become more "distanced" from Germany. The increasing solely foreign news coverage moves the respective topics and thus also countries in focus away from the sphere of relevance for Germany itself. Again, it has to be pointed out, however, that this shift in attention is also depending on the topic area taken into view.

With regard to the articles that also relate to the EU Presidency, the reference to German nationals decreases slightly throughout the Polish presidency term (3.3/2.1/2.4 percent before/during/after the presidency term), while before the term we also find a significant number of articles with references to both German nationals and impacts on Germany in the context of the topics discussed (2.0 percent). Most significantly, the predominant non-reference to Germany (solely foreign focus of the articles) reaches its highest share in the timeframe during the Polish EU Presidency (2.2 percent), indicating that with regard to topics relating to the EU Presidency and Poland, a significant share of the overall focus of the German news coverage is external.

The Role of Poland in the News Coverage on the EU Presidency

The last category to be introduced looks at the role that is ascribed to Poland in the German news coverage in articles that also relate to the EU Presidency (Table 13).

Table 13

Role of Poland in Articles Relating to the EU Presidency

\begin{tabular}{||l|c|c|c|c|c||}
\hline Role of Poland ... & $\begin{array}{c}\text { EU } \\
\text { member }\end{array}$ & $\begin{array}{c}\text { New EU } \\
\text { member }\end{array}$ & $\begin{array}{c}\text { Host of } \\
\text { a meeting }\end{array}$ & $\begin{array}{c}\text { Eastern or Central } \\
\text { European country }\end{array}$ & Other \\
\hline Pre-presidency & 80.0 & 20.0 & - & - & - \\
\hline During presidency & 83.1 & 8.5 & 3.4 & 3.4 & 1.7 \\
\hline Post-presidency & 60.0 & - & - & - & 40.0 \\
\hline \% of total sample & $\mathbf{8 1 . 1}$ & $\mathbf{9 . 5}$ & $\mathbf{2 . 7}$ & $\mathbf{2 . 7}$ & $\mathbf{4 . 1}$ \\
\hline
\end{tabular}

We see that the majority of the German articles that relate to the EU Presidency label Poland as an "EU member state", followed by the ascribed role of Poland being a "new EU member". Another 2.7 percent of the articles respectively refer to the country as an "Eastern or Central Eu- 
ropean country", or present Poland as the "host of a meeting". The role "EU member" is most often ascribed before and during the Polish presidency term, but significantly less after the term. In the pre-presidency period, the role as a "new EU member" is also frequently ascribed, but it also decreases in its usage during the presidency term, and it disappears completely after the term ended. This indicates that in the beginning of the presidency it seemed necessary for German newspapers to outline that Poland is still a young EU member state taking over the presidency for the first time, a fact that seemed less relevant to mention later on. Finally, the roles "host of a meeting" and "Eastern and Central European country" appear only during the Polish Presidency term. Being portrayed as the host of a meeting is an obvious reference in that period, since Poland is hosting a number of EU-level summits and meetings as the holder of the presidency.

\section{Discussion of Results and Conclusion}

Altogether, the results of our analysis show that the Polish EU Presidency term did not draw more attention to Poland in German print media news, despite its being the host of a number of EU events and meetings. The 6-month period of the presidency did also not lead to a significant increase of the complexity and composition of this news coverage and thus of the Polish image in German media. Thirdly, the fact that Poland for this period was also the actor in charge to define the directions of the EU policy is taken into view only in the very beginning of the Polish presidency term. Furthermore, a brief look at the content of the news articles focusing on the EU Presidency as well indicates that Poland and the EU Presidency are predominantly not the central focus in those articles. Often, the news simply report about events or actions carried out in the scope of this position. Thus, the relevance of Poland in both general and EU Presidency-related articles of the German news coverage is predominantly minor.

Nevertheless, when we look more closely at the evaluations of Poland made when the Polish EU Presidency is taken into view, we see that the communicated perception is rather neutral or even positive. Only few articles included explicitly negative or ambivalent evaluations. Thus, altogether the overall perception of Poland was not one-sided. Especially the positive pre-presidency evaluations of the country indicate rather positive expectations expressed towards the country's performance. Looking at the 
follow-up evaluations expressed throughout and after the term, those expectations were not disappointed, but they also did not lead to an increased relevance of and interest for Poland and Polish issues in the German media perception.

However, this lack of focus on the Polish presidency does not necessarily stem from a failure in the political performance (and marketing) of Poland. Rather, it may also be explained with other peculiarities of the German overall perception - of Poland but also of the EU. As previous international comparative studies on foreign news coverage have pointed out, in the last decades we see a marginalization of mass media's attention to foreign and international issues (Wouters, 2011). Additionally, for the German context two other peculiarities may be pointed out that may shape the overall focus on Poland in the news coverage:

Being one of the founding countries of the EU, Germany is one of the "EU-heavyweights", regarding its population size and its political standing. Furthermore, compared to other EU members, the country has a rather supportive position towards its own EU membership as well as to EU-related matters. This position was slightly shaken more recently by the EU financial crisis, but remains more positive still than in many other EU countries (Risse-Kappen, 2010). Therefore, in general the German news coverage centers more on the own obligations and performances on the European stage. Our analyzed news coverage reflects that notion, with the articles reporting much stronger about the own alignments, negotiations and positions, or that of other crucial EU players such as France, Great Britain, or of countries that are the center of temporary attention, as was the case for Greece due to its bankruptcy and the following EU bailout negotiations. This clearly interfered with and also overshadowed the Polish presidency news coverage.

On the other hand, classic concepts of news geography have pointed out that the media apply certain selection criteria in their definition of relevance in (foreign) news coverage. Those studies claim that the economic, social, political and geographic characteristics of a nation determine the amount of coverage one country receives in the media discourses of another. Additionally, historical relations, the index of economic development, the size of a country, cultural or geographic proximity, the language factor, elite status, or the availability of news sources are also crucial factors that influence newsworthiness (see especially Galtung, Ruge, 1965; Ostgaard, 1965; Staab, 1990; Rosengren, 1974; Stevenson \& Cole, 1984; Chang, Lee, 1992; Shoemaker, Cohen, 2006; Wu, 2000; Weber, 2010; 
Wilke et al., 2012). With regard to the other frames of perception that have been identified as crucial dimensions in the German news coverage on Poland, here, some of those factors apply, e.g., regionalism and geographic proximity.

Thirdly, based on their common history, Germany also has a special and not always conflict-free relationship to its neighboring country Poland. As Gatzke (2010) agues, the German perception of Poland can be described with to two crucial terms that form two ends of a continuum: admiration and rejection. To only name the most recent important historical ties - those include the military attack by Nazi Germany in the Second World War, the subsequent violent displacement of Germans from the Polish territories, the policy of détente after the breakdown of the Eastern European Communist regimes, the recent conflicts over compensation claims of German displaced people ( $2^{\text {nd }}$ World War), or the 2005 election campaign of the later Polish President Lech Kaczyński in 2005, which fueled anti-German resentments in Poland (Asmuss, Koch, 2009). Also, on the EU and international political level, topics such as the conflict over support for the 2003 Iraq War (Poland was pro-war, Germany against the military intervention), or the debate over the EU constitution and the weight of EU country votes also triggered new conflicts between Germany and Poland (Szarota, 2010; Gatzke, 2010). Especially the identified relevance of historical topics, but also EU-presidency-related news have to be observed against the background of those historical ties.

Gatzke (2010) also illustrates that since the 1990s Poland receives an ambivalent image in the German public perception - oscillating between the positive image supported by the economic and political elites and the negative perceptions of Polish people (in Poland but also immigrants in Germany) as being car thieves, cigarette smugglers or other organized criminals. Also with regard to EU-related topics, Gatzke (2010) argues that Poland is often communicated to symbolize the full spectrum of difficulties that the EU has to face in its enlargement process, spanning from issues such as unreported employment, wage competition, or power struggles among EU countries (Ociepka et al., 2008). Those aspects clearly become apparent from the topics and Polish portrayals in the context of the thematic areas "justice and crime" or "international/internal politics" when Polish criminals are taken into view or EU-related topics are covered. At the same time, Germany also has a large community of immigrants with Polish origin, most of whom came to Germany for example in the late 19th century due to the rapid industrialization in the Ruhr region, 
in the 1980s as political refugees during the internal political crisis in Poland (e.g., repression of the Solidarnosc movement), and after Poland joined the EU in 2004 (Boldt, 2012). Today, officially approximately 579.000 people of Polish origin reside in Germany, unofficial numbers are, however, assumed to be much higher (Statistisches Bundesamt, 2011: 8). This relevance of Polish immigrants in the country reflects in particular in the identified focus on the thematic areas "culture" and "sport", in which a few actors of Polish origin in Germany are taken into view.

Thus, for the German country case, we can conclude that the EU presidency has not offered the opportunity for Poland to significantly change its image as an EU player in the German media perception. It also did not change the overall thematic focus of the German news coverage on Poland, indicating that the overall German frames of perceptions remained unaltered.

\section{References}

Asmuss B., Ulrich B., Koch M. (eds.) (2009), 1.9.39: Deutsche und Polen: Abgründe und Hoffnungen, Sandstein, Dresden.

Boldt T. D. (2012), Die stille Integration: Identitätskonstruktionen von polnischen Migranten in Deutschland, Biographie- und Lebensweltforschung, Vol. 11, Campus, Frankfurt am Main.

Chang T. K., Lee J. W. (1992), Factors Affecting Gatekeepers' Selection of Foreign News: A National Survey of Newspaper Editors, "Journalism Quarterly", no. $69(3)$, pp. 554-561.

Galtung J., Ruge M. H. (1965), The Structure of Foreign News. The Presentation of the Congo, Cuba and Cyprus Crisis in Four Norwegian Newspapers, "Journal of Peace Research", no. 2, pp. 64-91.

Gatzke N. (2010), Polenbild in Deutschland: Wandel und Kontinuität-von Polen als Gegenbild der Aufklärung bis zur EU-Reformdebatte (Magisterarbeit), Universität Potsdam, Potsdam, Retrieved from http://www.ssoar.info/ssoar/handle/document/29050.

Hans-Bredow-Institut für Medienforschung (ed.) (2009), Internationales Handbuch Medien ( $28^{\text {th }}$ ed.), Nomos, Baden-Baden.

Lawaty A., Orłowski H. (eds.) (2003), Deutsche und Polen. Geschichte, Kultur, Politik, München.

Ociepka B., Łada A., Ćwiek-Karpowicz J. (2008), Die Europapolitik Warschaus und Berlins in der deutschen und polnischen Presse. Ein Forschungsbericht, Instytut Spraw Publicznych, Warschau, Retrieved from http://www.isp.org.pl/ files/4184425580093185001213726958.pdf. 
Ostgaard E. (1965), Factors Influencing the Flow of News, "Journal of Peace Research", no. 2, pp. 39-63.

Risse-Kappen T. (2010), A Community of Europeans? Transnational Identities and Public Spheres, Cornell University Press, Ithaca, NY.

Rosengren K. E. (1974), International News: Methods, Data and Theory, "Journal of Peace Research", no. 11, pp. 145-156.

Shoemaker P. J., Cohen A. A. (eds.) (2006), News around the World: Content, Practitioners, and the Public, Routledge, New York.

Staab J. F. (1990), The Role of News Factors in News Selection: A Theoretical Reconsideration, "European Journal of Communication", no. 5(4), pp. 423-443.

Statistisches Bundesamt (2012), Bevölkerung und Erwerbstätigkeit: Bevölkerung mit Migrationshintergrund - Ergebnisse des Mikrozensus 2011 (Fachserie 1 Reihe 2.2), Wiesbaden.

Stevenson R. L., Cole R. R. (1984), Issues in Foreign News, in: Foreign news and the new world information order, (eds.) R. L. Stevenson, D. L. Shaw, The Iowa State University Press, Ames, pp. 5-20.

Szarota T. (2010), Stereotype und Konflikte: Historische Studien zu den deutsch-polnischen Beziehungen, "Historische Dialoge", Vol. 1, Osnabrück: fibre.

Weber P. (2010), No News from the East? Predicting Patterns of Coverage of Eastern Europe in Selected German Newspapers, "International Communication Gazette", no. 72(6), pp. 465-485.

Wilke J., Heimprecht C., Cohen A. A. (2012), The Geography of Foreign News on Television: A Comparative Study of 17 Countries, "International Communication Gazette", no. 74(4), pp. 301-322.

World Editors Forum/World Association of Newspapers (ed.) (2009), World Press Trends 2008, Paris.

Wouters R. (2011), The Nature of Foreign News: Conceptual Considerations about Analysing Foreign News Over Time, in: News in Europe, Europe on news, (ed.) A. Stępińska, Logos, Berlin, pp. 43-62.

Wu H. D. (2000), Systemic Determinants of International News Coverage: A Comparison of 38 Countries, "Journal of Communication", no. 50(2), pp. 110-130.

Zernack K. (1991), Preußen - Deutschland - Polen. Aufsätze zur Geschichte der deutsch-polnischen Beziehungen, Wolfram Fischer und Michael Müller, Berlin.

\section{Abstract}

This paper summarizes the key features of the German print media news coverage on Poland throughout the timeframe of the Polish EU Presidency term in 2011. Results stem from a quantitative content analysis of three daily newspapers and one 
newsmagazine that were analyzed over a timeframe of 7 months from June 2011 to January 2012. Being one of the founding countries of the EU, Germany is one of the "EU-heavyweights", regarding its population size and its political standing. Furthermore, compared to other EU members, the country has a rather supportive position towards its own EU membership as well as to EU-related matters. This position was slightly shaken more recently by the EU financial crisis, but remains more positive still than in many other EU countries. However, Germany also has a very special and not always conflict-free relationship to its neighboring country Poland. Both aspects are crucial to bear in mind when the German news coverage on Poland during the presidency term is taken into view. The paper shows that the Polish EU presidency did not change the overall thematic focus of the German news coverage on Poland. The frame of perceptions of Poland shifted towards a more EU-related dimension only slightly and temporarily, but overall, deeper-rooted frames of perception as well as characteristic news factors shaped the German news coverage on Poland. 
